CARPATHIAN JOURNAL OF FOOD SCIENCE AND TECHNOLOGY

Journal home page: http://chimie-biologie.ubm.ro/carpathian_journal/index.html

\title{
INVESTIGATION OF PROPERTIES OF POLYSACCHARIDE-BASED EDIBLE FILM INCORPORATED WITH FUNCTIONAL MELASTOMA MALABATHRICUM EXTRACT
}

\author{
Chan, H.M. ${ }^{1}$, Nyam, K.L. ${ }^{1}$, Yusof, Y.A. ${ }^{2,3}$ and Pui, L.P. ${ }^{1 凶}$ \\ ${ }^{1}$ Department of Food Science with Nutrition, Faculty of Applied Sciences, UCSI University, No. 1, Jalan \\ Menara Gading, UCSI Heights, 56000 Cheras, Kuala Lumpur, Malaysia. \\ ${ }^{2}$ Department of Process and Food Engineering, Faculty of Engineering, Universiti Putra Malaysia, 43400 \\ UPM Serdang, Selangor, Malaysia. \\ ${ }^{3}$ Laboratory of Halal Services, Halal Products Research Institute, Universiti Putra Malaysia, 43400 \\ Selangor, Malaysia.

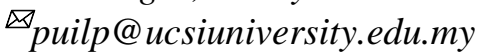 \\ https://doi.org/10.34302/crpifst/2020.12.1.12

\begin{tabular}{|c|c|}
\hline Article history: & $\overline{\text { ABSTRACT }}$ \\
\hline Received: & \multirow{17}{*}{$\begin{array}{l}\text { Edible film can be used to replace the usage of non-biodegradable } \\
\text { packaging material to reduce environmental pollution. In this study, three } \\
\text { types of polysaccharide-based edible films including chitosan, sodium } \\
\text { alginate and carboxymethyl cellulose (CMC) were made and compared for } \\
\text { their physical, mechanical and chemical properties. Sodium alginate had } \\
\text { the highest value of thickness }(0.08 \mathrm{~mm}) \text {, elongation at break }(42.70 \%) \text { and } \\
\text { puncture force }(13.26 \mathrm{~N}) \text {. Sodium alginate having the most suitable } \\
\text { properties, different concentrations of } 0-6 \% \text { (v/v) of Melastoma } \\
\text { malabathricum extract was incorporated into sodium alginate edible film } \\
\text { and its physical, antioxidant and antimicrobial properties were determined. } \\
\text { Melastoma malabathricum extract addition decreased the water activity } \\
\text { and elongation at break of the film. The incorporation of Melastoma } \\
\text { malabathricum extract did not significantly affect (p>0.05) the solubility, } \\
\text { puncture force and the antimicrobial properties of sodium alginate edible } \\
\text { film; while the antioxidant properties and the total phenolic content of the } \\
\text { edible film improved. Thus, it showed that with the addition of Melastoma } \\
\text { malabathricum extract into sodium alginate edible film, the functionality } \\
\text { of the film as an active packaging was enhanced. }\end{array}$} \\
\hline & \\
\hline & \\
\hline 2 March 2020 & \\
\hline Keywords: & \\
\hline Edible film; & \\
\hline Melastoma Malabathricum; & \\
\hline Antioxidant; & \\
\hline Antimicrobial. & \\
\hline & \\
\hline & \\
\hline & \\
\hline & \\
\hline & \\
\hline & \\
\hline & \\
\hline & \\
\hline
\end{tabular}

\section{Introduction}

Food packaging is an essential material used in food industry as it serves as containment and protection for food products to maintain the product quality and extend the shelf life of foods (Klimchuk and Krasovec, 2012). However, some packaging is mostly made up of non-biodegradable materials such as plastic that can cause a huge problem to the environment. Therefore, the development of edible packaging such as edible film has gained a lot of attention from researchers in the recent years to reduce environmental pollution. Edible film is a food grade thin layer of material that forms a physical barrier between food and surrounding, reducing the moisture loss and gas transport (Eca et al., 2014). Edible film can be made from polysaccharides film-forming material such as chitosan, sodium alginate and carboxymethyl cellulose (CMC) that has large variety of structural features with different forming properties, thereby influencing the physical properties of the film formed (Dhanapal et al., 2012).

Chitosan is a non-toxic and biodegradable polymer that is being widely used to form 
edible film due to its excellent mechanical and chemical properties (Suput et al., 2015). It has antimicrobial properties and widely used to extend the shelf life of fresh foods (Suput et al., 2015). Sodium alginate is the sodium salt of alginic acid, and it is isolated from brown seaweed (Embuscado and Huber, 2009). The film that made from sodium alginate is strong and soluble in water, acid and alkali. Sodium alginate film protects food against lipid oxidation due to its highly hydrophilic properties (Varela and Fiszman, 2011). Esmaeili and Fazel (2016) highlighted that cellulose derivative edible film is highly resistance to lipid and aromatic compound diffusion.

Edible films can be incorporated with food additives such as herbs and spices that has antimicrobial and antioxidant properties (Han, 2014). Jutaporn et al. (2011) found that the addition of Phayom wood extract into hydroxypropyl methylcellulose inhibits the growth of L. monocytogenes, S. aureus and E. coli. Chitosan edible film with the incorporation of galangal extract is found to have inhibitory effect against $S$. aureus by damaging the bacteria cell wall and cell membranes (Mayachiew et al., 2010). On the other hand, green tea extract can enhance the free radical scavenging effect of fish skin gelatin film (Wu et al., 2013). Also, in the work of Zaman et al. (2018), the application of edible with incorporated with Garcinia atrovirdis extract have prolonged the shelf life of fish. Choong et al (2019), however, added the musk lime extracts into chitosan edible film for the preservation of squid. Hence, the incorporation of herbs and spices with antimicrobial and antioxidant properties can reduce the growth of bacteria and improve the antioxidant properties of the film.

Melastoma Malabathricum, is known as 'senduduk'. It is a very common plant that can be found in tropical country. It grows as small trees and they can be found easily in forest or old defoliated area throughout the year (Susanti et al., 2007). The leaves, roots and shoots of Melastoma malabathricum extract has antimicrobial properties against some Gramnegative bacteria such as $S$. aureus and $B$. subtilis (Anbu et al., 2008). The bioactive compounds of Melastoma malabathricum such as quercetin and quercitrin have higher antioxidant effect than Vitamin E (Susanti et al., 2008).

To date, there is lack of studies on comparison of polysaccharide-based edible film. Hence, this study aimed to compare edible films from chitosan, sodium alginate and CMC based on their properties. The favourable polysaccharide-based edible film is determined based on its physical, mechanical and chemical properties. In addition, no report was found on the incorporation of Melastoma malabathricum extract into edible film. Thus, this study is followed by the incorporation of Melastoma malabathricum extract in different concentration into the chosen polysaccharidebased edible film to study the effect of Melastoma malabathricum extract on the physical, mechanical, chemical and antimicrobial properties of the edible film.

\section{Materials and methods \\ 2.1. Materials \\ 2.1.1. Samples}

Leaves of Melastoma Malabathricum were collected from the roadside to Genting Highland, Pahang, Malaysia. All the chitosan, sodium alginate and CMC, glycerol were of food grade, while the chemicals and reagents were of analytical grade.

\subsection{Preparation of Polysaccharide-based Edible Film}

\subsubsection{Chitosan}

The development of chitosan film was carried out according to Remya et al. (2016) with slight modification. Film forming solution was prepared by dissolving $1.5 \%(\mathrm{w} / \mathrm{v})$ chitosan in $100 \mathrm{~mL}$ of $1 \%$ acetic acid solution with constant stirring at room temperature. Glycerol was added into filtered solution at a concentration of $0.75 \% \quad(\mathrm{v} / \mathrm{v})$ followed by mixing for 15 minutes. Chitosan solution was 
casted onto a sterile petri dish and dried in a $40^{\circ} \mathrm{C}$ oven for 24 hours.

\subsubsection{Sodium alginate}

Sodium alginate film was prepared in accordance with the procedure described by Benavides et al. (2012) with slight modification. Sodium alginate solution was prepared by dissolving $1.5 \%(\mathrm{w} / \mathrm{v})$ of sodium alginate powder into $200 \mathrm{~mL}$ of distilled water followed by mixing for 30 minutes at temperature of $70^{\circ} \mathrm{C}$ and allowed to cool. Glycerol (0.75\% v/v) was added into the filtered solution as a plasticizer and the solution was stirred for 15 minutes. Sodium alginate solution was casted onto a petri dish and dried at $40^{\circ} \mathrm{C}$ for 24 hours in an oven.

\subsubsection{Carboxymethyl cellulose (CMC)}

Preparation of $\mathrm{CMC}$ film was conducted according to Savanjali et al. (2011) with slight modification. CMC powder was dissolved in $100 \mathrm{~mL}$ distilled water in $1.5 \%(\mathrm{w} / \mathrm{v})$ basis followed by filtration. Glycerol was added in a concentration of $0.75 \%(\mathrm{v} / \mathrm{v})$ as plasticizer and the solution was heated on flame for 10 minutes until the temperature of solution reached $85^{\circ} \mathrm{C}$. The solution was cooled for 30 minutes followed by casting onto a sterile petri dish. The petri dish was placed into a $40^{\circ} \mathrm{C}$ oven for 24 hours.

\subsection{Development Malabathricum alginate film}

\subsubsection{Chitosan}

Melastoma malabathricum extract following method by Sarbadhikary et al. (2015) with slight modification. Melastoma Malabathricum leaves were washed with tap water followed by rinsing with distilled water. The leaves were grinded into smaller pieces by using a waring blender after drying at ambient temperature for 1 day. Extraction was done by mixing $10 \mathrm{~g}$ leaves powder with $250 \mathrm{~mL}$ ethanol in a conical flask followed by for 48 hours at 150 rpm. Then, the solution was brought to centrifugation at $7000 \mathrm{rpm}$ for 15 minutes after filtration. Solvent in the supernatant was removed by using rotary evaporator with the temperature of $40^{\circ} \mathrm{C}$. Ethanolic extract formed in round bottom flask was weight and dissolved in ethanol to obtain leave extract with the concentration of $50 \mathrm{mg} / \mathrm{mL}$.

\subsubsection{Incorporation of Melastoma Malabathricum in sodium alginate film}

Melastoma Malabathricum incorporated sodium alginate film was prepared according to Benavides et al. (2012) with slight modification. Film forming solution was prepared by mixing $1.5 \%(\mathrm{w} / \mathrm{v})$ of sodium alginate powder with $200 \mathrm{~mL}$ of distilled water followed by mixing for 30 minutes at temperature of $70^{\circ} \mathrm{C}$ until dissolved. Glycerol $(0.75 \% \mathrm{v} / \mathrm{v})$ was added into the filtered film solution as a plasticizer. Melastoma malabathricum extract was added at concentration of $0 \%, 2 \%, 4 \%$ and $6 \%(\mathrm{v} / \mathrm{v})$, followed by homogenization for 3 minutes. Lastly, film forming solution was casted on a petri dish and dried at $40^{\circ} \mathrm{C}$ for 24 hours in an oven. For antimicrobial analysis, dried films were dipped in $2 \% \mathrm{CaCl} 2$ solution for 1 minutes to form an insoluble film prior to analysis.

\subsection{Antimicrobial Properties}

\subsubsection{Melastoma malabathricum}

Antimicrobial properties of Melastoma malabathricum extract was determined by using disc diffusion method as according to Sarbadhikary et al. (2015) with slight modification. Bacteria cultures (Staphylococcus aureus and Escherichia coli) were prepared and adjusted to the standard of McFarland No. 0.5 to achieve a concentration of approximately $108 \mathrm{cfu} / \mathrm{mL}$. Paper disc in the size of $6 \mathrm{~mm}$ diameter was impregnated with $50 \mu \mathrm{L}$ of Melastoma malabathricum extract and placed onto inoculated agar. Antibiotic disc and paper disc impregnated with $50 \mu \mathrm{L}$ of ethanol was placed on agar as positive control and negative control, respectively. The inoculated plates were then brought to incubation at $37^{\circ} \mathrm{C}$ for 18 24 hours. The antimicrobial activity of extract 
was determined by measuring the zone of inhibition (including the diameter of disc) formed against the bacteria tested.

\subsubsection{Melastoma malabathricum incorporated sodium alginate film}

Films were cut into $6 \mathrm{~mm}$ diameter sphere by using a hole puncture and placed onto the inoculated agar. On the other hand, a $30 \mu \mathrm{g}$ chloramphenicol disc and film without leaves extract were also placed onto the inoculated agar as positive control and negative control, respectively. The inoculated plates were brought to incubation at $37^{\circ} \mathrm{C}$ for $18-24$ hours. The antimicrobial activity of films was determined by measuring the zone of inhibition (including the diameter of disc) formed against the bacteria tested.

\subsection{Antioxidant Properties}

\subsubsection{Antioxidant activity}

Antioxidant effect of Melastoma malabathricum extract was determined by using DPPH (2,2-diphenyl-1-picrylhydrazyl) free radical scavenging assay, according to Wong et al. (2014) with slight modification. T Melastoma malabathricum extract $(0.1 \mathrm{~mL})$ was added into $3.9 \mathrm{~mL} 0.004 \%$ ethanolic DPPH solution in a test tube followed by incubation in dark for 30 minutes. The absorbance of the mixture was measured at $517 \mathrm{~nm}$ using UV-Vis Spectrophotometer. Ethanol was used to zero the instrument prior to sample reading. The percentage of DPPH scavenging effect was calculated by using equation below. Leave extract was replaced with film extract that was prepared by dissolving $25 \mathrm{mg}$ of film into $3 \mathrm{~mL}$ of distilled water.

DPPH Scavenging effect $(\%)=\frac{\text { Abs of DPPH }- \text { Abs of sample }}{\text { Abs of DPPH }} \times 100$

where Abs of DPPH is the absorbance value of $0.004 \%$ ethanolic DPPH solution and Abs of sample is the absorbance value of extract at 517 $\mathrm{nm}$, respectively.

\subsubsection{Total phenolic content}

Total phenolic content of Melastoma malabathricum extract was determined by using Folin-Ciocalteu method as according to Wong et al. (2014) with slight modification. Ten times diluted Melastoma malabathricum was added into a wrapped test tube in the amount of $0.3 \mathrm{~mL}$ followed by the addition of $1.5 \mathrm{~mL}$ Folin-Ciocalteu's reagent and $1.2 \mathrm{~mL}$ sodium carbonate. The mixture was placed in dark for 30 minutes prior to the absorbance reading at $765 \mathrm{~nm}$. Gallic acid solution prepared in specific concentration $(0,0.025$, 0.050 and $0.100 \mathrm{mg} / \mathrm{g}$ ) was used to generate a standard curve. Leave extract was replaced with film extract that was prepared by dissolving $25 \mathrm{mg}$ of film into $3 \mathrm{~mL}$ of distilled water.

\subsection{Film Analysis}

\subsubsection{Thickness}

The thickness of edible films was measured by using a micrometer with accuracy of $0.01 \mathrm{~mm}$. Measurements were taken at five different locations of each film and the average film thickness was calculated to ensure consistent results (Muppalla et al. 2014).

\subsubsection{Water solubility}

Water solubility of edible films was determined according to the method by $\mathrm{Ma}$ et al. (2016) with slight modification. Edible films were cut into $2 \mathrm{~cm} \times 2 \mathrm{~cm}$ dimension followed by drying at $60^{\circ} \mathrm{C}$ for 24 hours. The weight of dried films (W1) was determined and recorded accordingly. Each dried film was immersed in $25 \mathrm{~mL}$ of distilled water for 2 hours at room temperature. The films were then dried in oven at $60^{\circ} \mathrm{C}$ for 24 hours. Final mass of dried films (W2) was weight and recorded after cooling to room temperature. The water solubility of films was calculated following equation.

$$
\text { Water solubility }=\frac{W_{1}-W_{2}}{W_{1}} \times 100 \%
$$




\subsubsection{Water activity}

Water activity of films was determined by using water activity meter (AquaLab Pre, USA). Edible films were cut into $3 \mathrm{~cm} \times 3 \mathrm{~cm}$ dimension, placed into a sample cup and sample drawer prior measuring the water activity.

\subsubsection{Colour}

Colour of the film was determined using colorimeter (ColorFlex EZ, Australia). A $3 \mathrm{~cm}$ x $3 \mathrm{~cm}$ film was placed on a ColorFlex sample cup for colour determination. The film colour result was generated in terms of $\mathrm{L}^{*}, \mathrm{a}^{*}$, and $\mathrm{b}^{*}$, where $\mathrm{L}^{*}$ represents darkness when $\mathrm{L}=0$ and brightness when $\mathrm{L}=100$; $\mathrm{a}^{*}$ represents green hue in negatives value and red hue in positive value; $b^{*}$ represents yellow-blue with positive value indicates yellow and negative value indicates blue. The colour index $(\Delta \mathrm{E})$ that identifies the total colour changes between each sample of Melastoma Malabathricum incorporated sodium alginate films was calculated according to the equation [4] (Hernandez-Hernandez et al., 2009).

$$
\Delta E=\sqrt{(L *-L)^{2}+(a *-a)^{2}+(b *-b)^{2}}
$$

where $L^{*}, a^{*}$ and $b^{*}$ are the colour parameter values of the pure sodium alginate edible film and $\mathrm{L}, \mathrm{a}$, and $\mathrm{b}$ are the colour parameter values of the Melastoma Malabathricum incorporated sodium alginate films.

\subsubsection{Tensile strength and elongation at break}

Tensile test was conducted with a universal material tester (LF1096, UK) in accordance with ASTM standard method as described by Remya et al. (2016). The films (60 mm x 10 $\mathrm{mm}$ ) were clamped between grips with an initial separation of $40 \mathrm{~mm}$, and the cross-head speed was set at $20 \mathrm{~mm} / \mathrm{min}$. Tensile strength and elongation at break were measured. Tensile strength and elongation at break were calculated by using the equations below, respectively.
Tensile strength $=\frac{\text { Peak load }(N)}{\text { Cross }- \text { sectional area }\left(\mathrm{mm}^{2}\right)}$

Elongation at break point $=\frac{\text { Final length of film ruptured }(\mathrm{mm})}{\text { Initial grip length }(\mathrm{mm})} \times 100 \%$

(Eq.5)

2.6.6. Fourier transform infrared spectroscopy (FTIR)

The absorbance spectra of films were determined using Fourier Transform Infrared (FTIR) spectrometry connected to OMNIC Spectra Software in transmission mode. Films were placed on the sample holder and fixed by a tiny probe. Spectra of films were obtained with a resolution of $4 \mathrm{~cm}^{-1}$ as the average of 20 scans in the range of $500 \mathrm{~cm}^{-1}$ to $4000 \mathrm{~cm}^{-1}$ against a background spectrum from an empty cell.

\subsection{Statistical Analysis}

The experimental data was analyzed using IBM SPSS version 20 software. One-way Analysis of Variance (ANOVA) was used to analyse data obtained from film analysis whereas independent sample T-test was performed for the antimicrobial properties of Melastoma malabathricum. The p-value of $\leq 0.05$ was considered as statically significant.

\section{Results and discussions}

3.1. Comparison between different polysaccharide-based edible films

3.1.1. Physical and Mechanical Properties of Different Polysaccharide-based Edible Films

From the result obtained in Table 1, the thickness of chitosan, sodium alginate and CMC edible film was determined as $0.06 \mathrm{~mm}$, $0.08 \mathrm{~mm}$ and $0.04 \mathrm{~mm}$, respectively. RossiMarquez et al. (2009) found that film thickness will affect the elasticity (E\%) of the film where thicker films had higher elasticity than thinner films due to greater amount of material per unit length, while Ghasemlou et al. (2011) stated that thinner film is difficult to handle. Based on the result, sodium alginate film has the highest thickness value among three edible films 
indicating stronger mechanical properties, higher protecting effect for food products.

Water solubility of edible films determines the biodegradability and integrity of the films in an environment with higher relative humidity (Ma et al., 2016). It affects the application of the films on food products (Maizura et al., 2007). Result shows that sodium alginate and CMC are $100 \%$ soluble in water whereas chitosan is only $25.60 \%$ soluble in water. Alginate and cellulose film have poor water resistance owing to the hydrophilic nature of the materials (Dhanapal et al., 2012). The presence of hydrophobic acetyl group in the structure of chitosan reduces the solubility of chitosan in water (Bangyekan et al., 2006).

Chitosan, sodium alginate and CMC edible film have the water activity value of 0.571 , 0.524 and 0.545 , respectively (Table 1$)$. The water activity level of all three polysaccharidebased edible films is below the minimum threshold for the growth of microorganism (Barbosa-Cánovas, 2007). Based on the result obtained, there is no significant difference ( $p>0.05$ ) between the water activity of all three edible films.

Colour is one of the important parameters for food packaging as it will affect the appearance of the food product. Chitosan edible film is the lightest among the three edible films, followed by sodium alginate and CMC. The more negative $\mathrm{a}^{*}$ value obtained for chitosan film indicate that chitosan has higher intensity of green colour compared to the other two edible films. The physical appearance of chitosan edible film in this study show lighter yellowness and thus it has a positive value (0.74) in $b^{*}$ parameter. Ojagh et al. (2010a) reported that chitosan edible film is slightly yellowish.

Sodium alginate and CMC edible films developed in this study are transparent which indicate that the food product appearance will not be affected by the film. Hence, sodium alginate and $\mathrm{CMC}$ are more suitable to be used as food packaging for protecting effect.

Table 1. Physical and mechanical properties of chitosan, sodium alginate and CMC edible films

\begin{tabular}{|c|c|c|c|}
\hline Films & Chitosan & Sodium alginate & CMC \\
\hline Thickness $(\mathrm{mm})$ & $0.06 \pm 0.01^{\mathrm{a}}$ & $0.08 \pm 0.01^{\mathrm{b}}$ & $0.04 \pm 0.01^{\mathrm{a}}$ \\
\hline $\begin{array}{c}\text { Water solubility } \\
(\%)\end{array}$ & $25.60 \pm 0.90^{\mathrm{a}}$ & $100.00 \pm 0.00^{\mathrm{b}}$ & $100.00 \pm 0.00^{\mathrm{b}}$ \\
\hline Water activity & $0.571 \pm 0.025^{\mathrm{a}}$ & $0.524 \pm 0.036^{\mathrm{a}}$ & $0.545 \pm 0.031^{\mathrm{a}}$ \\
\hline$L^{*}$ & $13.28 \pm 0.13^{\mathrm{a}}$ & $7.36 \pm 0.85^{\mathrm{b}}$ & $6.15 \pm 0.57^{\mathrm{b}}$ \\
\hline$a^{*}$ & $-1.67 \pm 0.25^{\mathrm{a}}$ & $-0.28 \pm 0.05^{\mathrm{b}}$ & $-0.22 \pm 0.04^{\mathrm{b}}$ \\
\hline$b^{*}$ & $0.74 \pm 0.07^{\mathrm{a}}$ & $-0.94 \pm 0.01^{\mathrm{b}}$ & $-0.82 \pm 0.14^{\mathrm{b}}$ \\
\hline $\begin{array}{c}\text { Tensile strength } \\
(\mathrm{MPa})\end{array}$ & $15.45 \pm 1.25^{\mathrm{a}}$ & $17.17 \pm 0.16^{\mathrm{a}}$ & $12.61 \pm 1.46^{\mathrm{b}}$ \\
\hline $\begin{array}{c}\text { Elongation at } \\
\text { break (\%) }\end{array}$ & $7.83 \pm 0.76^{\mathrm{a}}$ & $42.70 \pm 1.26^{\mathrm{c}}$ & $23.84 \pm 3.09^{\mathrm{b}}$ \\
\hline Puncture force $(\mathrm{N})$ & $7.17 \pm 1.01^{\mathrm{a}}$ & $13.26 \pm 2.39^{\mathrm{b}}$ & $9.24 \pm 0.54^{\mathrm{a}}$ \\
\hline
\end{tabular}

${ }^{\mathrm{a}-\mathrm{c}}$ Means \pm standard deviations followed by different superscript letters within the same row are significantly different at $\mathrm{p} \leq 0.05$ according to Tukey's test.

Tensile strength is the maximum stress that can be withstand by the sample and higher tensile strength is usually preferable for a material (Bourtoom and Chinnan, 2008). Based on the result in Table 1, no significant difference $(\mathrm{p}>0.05)$ were found between the tensile strength of chitosan and sodium alginate, with the value of 15.45 $\mathrm{MPa}$ and 17.17 MPa, respectively. However, the tensile strength of $\mathrm{CMC}$ with the value 
of $12.61 \mathrm{MPa}$ is lower than chitosan and sodium alginate edible film. Chitosan and sodium alginate edible film have higher tensile strength compared to CMC edible film, indicating that chitosan and sodium alginate edible films are stronger than CMC edible films.

Elongation at break describes the plasticity and the ability of the film to stretch and extend before breaking into half (Maran et al., 2013). Generally, film with higher plasticity or extensibility is favourable, as the integrity of the film can be maintained when applied onto food products (Arham et al., 2016). As shown in Table 1, among the elongation at break of chitosan, sodium alginate and CMC edible film, sodium alginate has the highest elongation at break value. Alginate was reported to produce stronger film (Maizura et al. 2007). Hence, sodium alginate is selected to be a food packaging as it will not break easily.

Puncture force can be defined as the maximum force required to pierce or break a certain type of material (Maran et al., 2013). Based on the result obtained in Table 1, sodium alginate edible film has highest puncture force $(13.26 \mathrm{~N})$ among chitosan and CMC edible film $(7.17 \mathrm{~N}$ and $9.24 \mathrm{~N}$, respectively). It is expected that thicker film has higher puncture force value (Gimenez et al., 2009). Sodium alginate edible film was found to have the highest thickness value among three polysaccharide-based edible films. Higher puncture force value makes sodium alginate more suitable to be used as a food packaging compared to chitosan and CMC edible film as films with higher puncture force may be able to withstand higher external force.

\subsubsection{Chemical Properties of Different Polysaccharide-based Edible Films}

The analysis of FTIR was carried out to identify the functional groups present in chitosan, sodium alginate and $\mathrm{CMC}$ edible films by the bands generated from spectra (Su et al., 2010). Figure 1 (a) represents the absorption spectra of chitosan edible film. The broad spectrum at $3281 \mathrm{~cm}^{-1}$ represents the intermolecular hydrogen bonding of chitosan as well as the stretching vibration of $\mathrm{N}-\mathrm{H}$ and $\mathrm{O}-\mathrm{H}$ groups (Pranoto et al., 2005a). Absorption peak at $2877 \mathrm{~cm}^{-1}$ and $1557 \mathrm{~cm}^{-1}$ representing the stretching vibration of $\mathrm{C}-\mathrm{H}$ bond and $\mathrm{N}-\mathrm{H}$ band for either amide II or primary amine, respectively (Jawaid et al., 2016). The most intense peak at $1021 \mathrm{~cm}^{-1}$ in chitosan edible films represents the $\mathrm{C}=\mathrm{O}$ and $\mathrm{C}-\mathrm{N}$ groups stretching.

Figure 1 (b) presents the spectra of sodium alginate edible film. The spectrum has a broad absorption band at $3265 \mathrm{~cm}^{-1}$ indicates the stretching vibration of $\mathrm{OH}$ groups whereas the absorption peak at 2938 $\mathrm{cm}^{-1}$ indicates the $\mathrm{C}-\mathrm{H}$ and $\mathrm{C}-\mathrm{O}$ stretching of the carboxyl group (Fang, 2016). Two characteristic absorption band of sodium alginate were identified at $1408 \mathrm{~cm}^{-1}$ and $1600 \mathrm{~cm}^{-1}$, indicating the symmetric and asymmetric stretching vibration of COOgroup, respectively (Dai et al., 2008). The absorption peak of sodium alginate at 1317 $\mathrm{cm}^{-1}$ and $1089 \mathrm{~cm}^{-1}$ are a sign of oligosaccharides while the most intense peak at $1025 \mathrm{~cm}^{-1}$ referring to the $\mathrm{C}-\mathrm{O}$ bonds of saccharide structure as well as the presence of guluronic acids (Mishra 2015).

Figure 1 (c) shows the spectra of CMC edible films. The broad absorption band of $\mathrm{CMC}$ at $3276 \mathrm{~cm}^{-1}$ represents the stretching vibration of hydroxyl group while the absorption peak at $2882 \mathrm{~cm}^{-1}$ indicates the stretching vibration of $\mathrm{C}-\mathrm{H}$ groups (Hebeish et al., 2013). Other absorption peak of CMC edible film was found at $1413 \mathrm{~cm}^{-1}$ and 1321 $\mathrm{cm}-1$, which represents the bending vibration $-\mathrm{CH}_{2}$ and $-\mathrm{OH}$ group respectively (Biswal and Singh, 2004). 


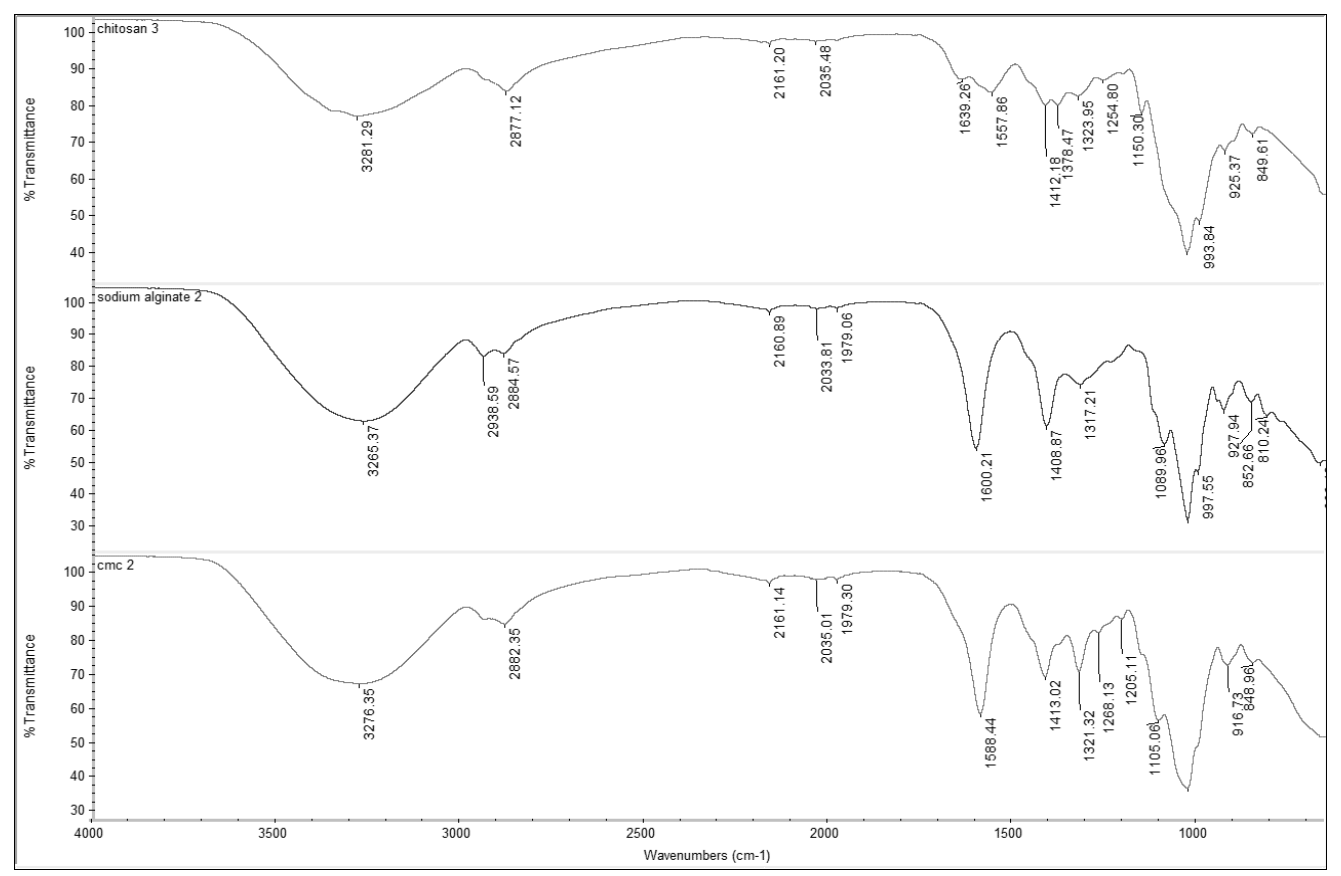

Figure 1. Spectra of Fourier Transform Infrared (FTIR) of (a) chitosan, (b) sodium alginate and (c) CMC edible films.

\subsubsection{Selection of polysaccharide-based edible film}

Edible film made from sodium alginate has better mechanical properties in the aspect of elongation at break and puncture force as compared to chitosan and CMC edible films. In addition, sodium alginate edible film possesses good physical properties such as colourless and water soluble which make it more suitable to be a packaging material. Hence, sodium alginate was selected for the incorporation of Melastoma malabathricum.

\subsection{Analysis of Melastoma malabathricum extract}

\subsubsection{Antimicrobial Properties}

Melastoma malabathricum extract was found to inhibit the growth of $S$. aureus as it has the inhibition zone of $10.44 \mathrm{~mm}$. However, Melastoma malabathricum extract showed no inhibitory effect towards E. coli. The structure of the bacterial cell wall. $S$. aureus is Gram-positive bacteria while $E$. coli is Gram-negative bacteria. According to

Nazzaro et al. (2013), the cell wall of Gram-negative bacteria contains lipopolysaccharide, which link the membranes together which create a protecting zone at the cell wall. This unique structure of Gram-negative bacteria causes active compound that has antimicrobial properties are difficult to penetrate through the bacteria cell wall and hence no inhibitory effect was shown.

\subsubsection{Antioxidant Properties and Total Phenolic Content}

Result shows that Melastoma malabathricum extract has the scavenging effect of $82.91 \%$. The antioxidant properties of Melastoma Malabathricum is owing to the presence of flavonoid compounds such as quercetin and quercitrin (Susanti et al., 2008). Result shows that Melastoma malabathricum contains phenolic content of $909.22 \mathrm{mg}$ GAE/100 g. According to 
Suhaimy et al. (2017), total phenolic content value higher than $1000 \mathrm{mg} \mathrm{GAE} / 100 \mathrm{~g}$ is considered as high total phenolic content.

\subsection{Analysis of Melastoma malabathricum sodium alginate films}

3.3.1. Physical and Mechanical Properties of Melastoma Malabathricum incorporated sodium alginate films

According to Table 2, the thickness of the films was increased from $0.08 \mathrm{~mm}$ to $0.10 \mathrm{~mm}$ when the concentrations of Melastoma malabathricum extract increased from $0 \%$ to $6 \%(\mathrm{v} / \mathrm{v})$. There is no significant difference $(p>0.05)$ in the thickness of sodium alginate with $0 \%$ to $4 \%$ (v/v) Melastoma malabathricum extract. However, the thickness of sodium alginate + 6\% Melastoma malabathricum extract edible film was $0.10 \mathrm{~mm}$, shown to be higher than the thickness of sodium alginate edible films with $0 \%, 2 \%$ and $4 \%(\mathrm{v} / \mathrm{v})$ Melastoma malabathricum extract.

The addition of Melastoma malabathricum extract does not affect the solubility of sodium alginate edible film as there was no significant difference $(p>0.05)$ between the solubility of sodium alginate edible films and pure sodium alginate film. The sodium alginate edible films were dissolved completely in water within 2 hours. Water activity of sodium alginate edible films decreased from 0.524 to 0.424 when the concentrations of Melastoma malabathricum extract was increased from $0 \%$ to $2 \%(\mathrm{v} / \mathrm{v})$. However, there is no significant difference $(\mathrm{p}>0.05)$ in the water activity of sodium alginate edible film incorporated with $2 \%, 4 \%$ and $6 \%(\mathrm{v} / \mathrm{v})$ of Melastoma malabathricum extract.

Table 2 shows that the lightness value (L*) of sodium alginate edible films increased when Melastoma malabathricum extract concentration increased from $0 \%$ to $6 \%(\mathrm{v} / \mathrm{v})$. A decrement trend of $\mathrm{a}^{*}$ value from -0.28 to -2.50 indicating an increasing intensity of greenness. The yellow-blue $\left(b^{*}\right)$ value of sodium alginate edible films were increased from -0.94 to 2.58 with the increased concentrations of Melastoma malabathricum extract. The yellow intensity of edible films increased when more Melastoma malabathricum extract was added into the film. The increment of green and yellow colour may be attributed to the colour nature of Melastoma malabathricum extract, which is yellowish-green visually. The addition of Melastoma malabathricum extract into sodium alginate edible film has resulted in an increasing trend of total colour change $(\Delta \mathrm{E})$ from 5.92 to 13.06 . Generally, the incorporation of Melastoma malabathricum extract caused the reduction in transparency of sodium alginate edible film where the colour of the films turns yellowish-green after the incorporation of Melastoma malabathricum. With increase in concentrations of Melastoma malabathricum extract, the green and yellow intensity were increased due to the yellowish-green of Melastoma malabathricum.

Table 2. Physical and mechanical properties of sodium alginate edible films with different concentration of Melastoma malabathricum extract

\begin{tabular}{|c|c|c|c|c|}
\hline $\begin{array}{c}\text { Melastoma } \\
\text { malabathricum } \\
(\%)\end{array}$ & 0 & 2 & 4 & 6 \\
\hline Thickness (mm) & $0.08 \pm 0.01^{\mathrm{a}}$ & $0.08 \pm 0.01^{\mathrm{a}}$ & $0.09 \pm 0.01^{\mathrm{a}}$ & $0.08 \pm 0.01^{\mathrm{a}}$ \\
\hline $\begin{array}{c}\text { Water solubility } \\
(\%)\end{array}$ & $100.00 \pm 0.00^{\mathrm{a}}$ & $100.00 \pm 0.00^{\mathrm{a}}$ & $100.00 \pm 0.00^{\mathrm{a}}$ & $100.00 \pm 0.00^{\mathrm{a}}$ \\
\hline Water activity & $0.524 \pm 0.036^{\mathrm{a}}$ & $0.424 \pm 0.012^{\mathrm{b}}$ & $0.417 \pm 0.006^{\mathrm{b}}$ & $0.524 \pm 0.036^{\mathrm{a}}$ \\
\hline
\end{tabular}




\begin{tabular}{|c|c|c|c|c|}
\hline$L^{*}$ & $7.36 \pm 0.85^{\mathrm{a}}$ & $13.17 \pm 0.38^{\mathrm{b}}$ & $17.28 \pm 0.32^{\mathrm{c}}$ & $7.36 \pm 0.85^{\mathrm{a}}$ \\
\hline$a^{*}$ & $-0.28 \pm 0.05^{\mathrm{a}}$ & $-1.32 \pm 0.12^{\mathrm{b}}$ & $-2.06 \pm 0.10^{\mathrm{c}}$ & $-0.28 \pm 0.05^{\mathrm{a}}$ \\
\hline$b^{*}$ & $-0.94 \pm 0.01^{\mathrm{a}}$ & $-1.36 \pm 0.08^{\mathrm{b}}$ & $0.84 \pm 0.10^{\mathrm{c}}$ & $-0.94 \pm 0.01^{\mathrm{a}}$ \\
\hline $\begin{array}{c}\text { Tensile strength } \\
(\mathrm{MPa})\end{array}$ & - & $5.92 \pm 0.38^{\mathrm{a}}$ & $10.24 \pm 0.31^{\mathrm{b}}$ & - \\
\hline $\begin{array}{c}\text { Elongation at } \\
\text { break (\%) }\end{array}$ & $17.17 \pm 0.16^{\mathrm{a}}$ & $16.03 \pm 0.64^{\mathrm{a}}$ & $22.91 \pm 1.27^{\mathrm{b}}$ & $17.17 \pm 0.16^{\mathrm{a}}$ \\
\hline $\begin{array}{c}\text { Puncture force } \\
(\mathrm{N})\end{array}$ & $42.70 \pm 1.26^{\mathrm{a}}$ & $40.16 \pm 0.43^{\mathrm{a}}$ & $32.87 \pm 1.90^{\mathrm{b}}$ & $42.70 \pm 1.26^{\mathrm{a}}$ \\
\hline
\end{tabular}

${ }^{\mathrm{a}-\mathrm{d}}$ Means \pm standard deviations followed by different superscript letters within the same row are significantly different at $\mathrm{p} \leq 0.05$ according to Tukey's test.

The addition of Melastoma malabathricum extract from $0 \%$ to $6 \%(\mathrm{v} / \mathrm{v})$ has improved the tensile strength of the edible film, from $17.17 \mathrm{MPa}$ to $24.33 \mathrm{MPa}$. Tensile strength of sodium alginate edible film incorporated with $6 \%(\mathrm{v} / \mathrm{v})$ Melastoma malabathricum extract was determined as 24.33 MPa, which showed no significant difference $(p>0.05)$ to the tensile strength of sodium alginate edible film incorporated with $4 \%(\mathrm{v} / \mathrm{v})$ Melastoma malabathricum; extract whereas the elongation at break of the edible films was in a decreasing trend with the increasing concentrations of Melastoma malabathricum extract.

The elongation at break was reduced from $42.70 \%$ to $29.05 \%$ when the concentrations of Melastoma malabathricum extract ranging from $0 \%$ to $6 \%(\mathrm{v} / \mathrm{v})$. According to Hosseini et al. (2009), water is the most abundant plasticizer for most hydrocolloid-based films such as alginate as it can alter the polymer structure. The incorporation of Melastoma malabathricum extract into sodium alginate edible film does not significantly affect $(p>0.05)$ the puncture force of the films.

\subsubsection{Chemical Properties of Melastoma Malabathricum incorporated sodium alginate films}

FTIR was used to study the interaction between sodium alginate and Melastoma malabathricum extract in this study. Figure
2 provides the spectra of sodium alginate edible films incorporated with different concentrations of Melastoma malabathricum extract. All spectra have shown similar absorption peak around $3263 \mathrm{~cm}^{-1}, 2938 \mathrm{~cm}^{-}$ ${ }^{1}$ and $1408 \mathrm{~cm}^{-1}$. According to Fang (2016), the absorption band around $3263 \mathrm{~cm}^{-1}$ represents the presence of $\mathrm{OH}$ group stretching whereas the peak around 2938 $\mathrm{cm}^{-1}$ indicates the $\mathrm{C}-\mathrm{H}$ and $\mathrm{C}-\mathrm{O}$ stretching of the carboxyl group. The absorption band around $1408 \mathrm{~cm}^{-1}$ specifies to the carboxylic group (COO-) (Pranoto et al., 2005b). Another absorption peak was obtained at around $1600 \mathrm{~cm}^{-1}$ and $1025 \mathrm{~cm}^{-1}$, which $1600 \mathrm{~cm}^{-1}$ represented the carboxylic group stretching vibration of either phenolic acids or uronic acids whereas $1025 \mathrm{~cm}^{-1}$ indicates the C-O stretching for phenolic acids (Khoo et al., 2014).

In the $4 \%$ and $6 \%(\mathrm{v} / \mathrm{v})$ Melastoma Malabathricum incorporated sodium alginate films, there is a small peak present at $1231 \mathrm{~cm}^{-1}$, indicating the presence of $(\mathrm{C}$ O) phenolic hydroxyl group in the film (Salbiah et al., 2010). However, there is no peak shown at $1231 \mathrm{~cm}^{-1}$ for $2 \%$ Melastoma malabathricum sodium alginate edible film. This may be caused by insufficient of the phenolic hydroxyl group to cause a peak at $1231 \mathrm{~cm}^{-1}$. The small peak area at $1231 \mathrm{~cm}^{-1}$ is due to the presence of phenolic compounds such as kaempferol and naringenin which its structure consists 
phenolic hydroxyl group (Susanti et al., 2008).

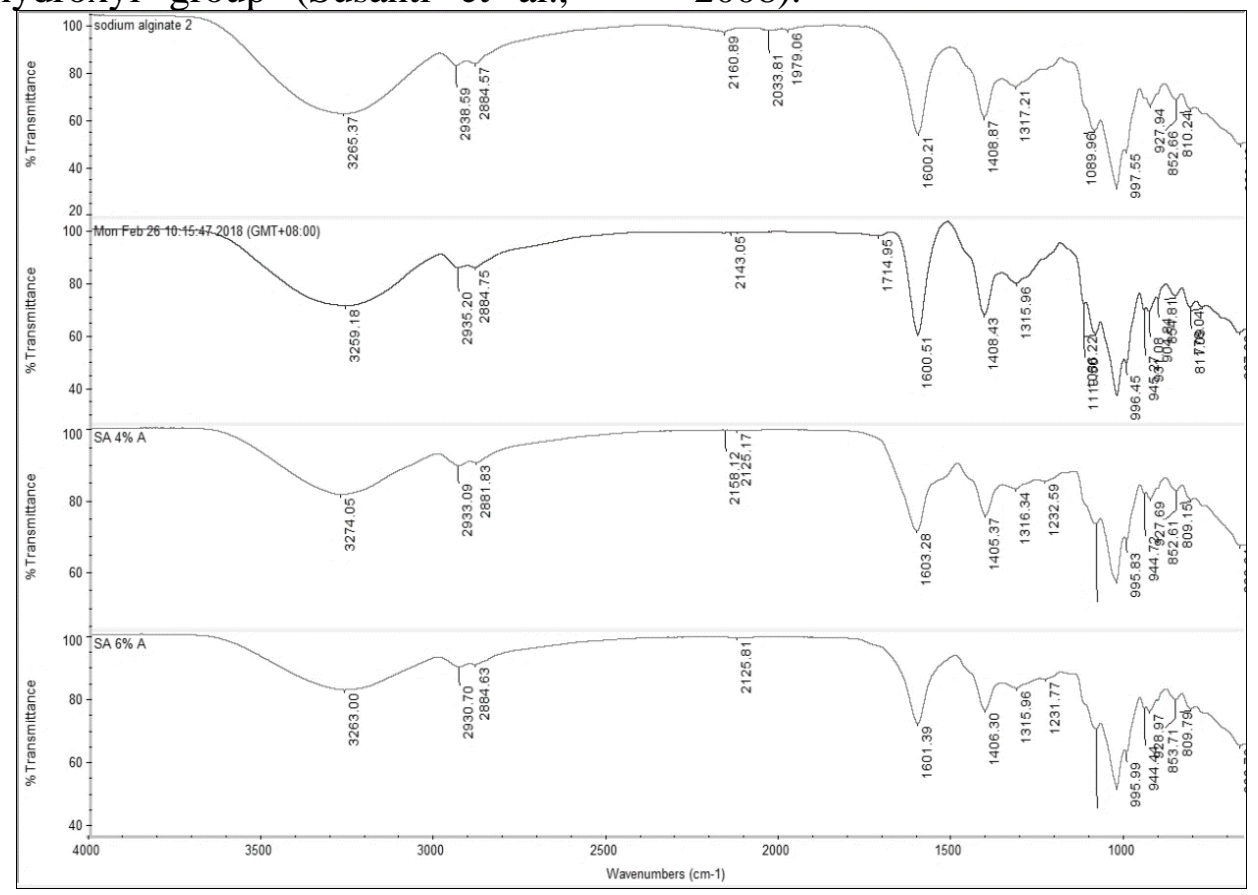

Figure 2. Spectra of Fourier Transform Infrared (FTIR) of Melastoma malabathricum sodium alginate edible films (a) $0 \%$ extract (b) $2 \%$ extract (c) $4 \%$ extract (d) $6 \%$ extract

Table 3 shows that sodium alginate film has scavenging effect with the value of $5.49 \%$. There is no significant difference ( $>0.05)$ found between the scavenging effect of $0 \%$ and $2 \%$ Melastoma Malabathricum incorporated sodium alginate films. With the increase of Melastoma malabathricum into sodium alginate edible films from $2 \%(\mathrm{v} / \mathrm{v})$ to $6 \%$ $(\mathrm{v} / \mathrm{v})$, the scavenging effect increase from
$7.12 \%$ to $26.32 \%$. Based on the result in Table 3, an increment in total phenolic content sodium alginate edible film was observed by the increasing concentrations of Melastoma malabathricum extract ranging from $0 \%$ to $6 \%(\mathrm{v} / \mathrm{v})$, where the total phenolic content of films was increased from $28.58 \mathrm{mg} \mathrm{GAE} / 100 \mathrm{~g}$ to $621.17 \mathrm{mg}$ $\mathrm{GAE} / 100 \mathrm{~g}$.

Table 3. scavenging effect, total phenolic content and inhibitory effect of sodium alginate edible films with different concentration of Melastoma malabathricum extract

\begin{tabular}{|c|c|c|c|c|}
\hline $\begin{array}{c}\text { Melastoma } \\
\text { malabathricum }(\%)\end{array}$ & 0 & 2 & 4 & 6 \\
\hline Scavenging effect (\%) & $5.49 \pm 0.73^{\mathrm{a}}$ & $7.12 \pm 0.74^{\mathrm{a}}$ & $19.47 \pm 1.42^{\mathrm{b}}$ & $26.32 \pm 3.69^{\mathrm{c}}$ \\
\hline $\begin{array}{c}\text { Total phenolic content } \\
\text { (mg GAE/100 g) }\end{array}$ & $28.58 \pm 2.59^{\mathrm{a}}$ & $305.42 \pm 29.21^{\mathrm{b}}$ & $443.10 \pm 47.30^{\mathrm{c}}$ & $621.17 \pm 56.84^{\mathrm{d}}$ \\
\hline $\begin{array}{c}\text { Inhibitory effect } \\
\text { against } \text { S. aureus } \\
(\mathrm{mm})\end{array}$ & $0.00 \pm 0.00^{\mathrm{a}}$ & $0.00 \pm 0.00^{\mathrm{a}}$ & $0.00 \pm 0.00^{\mathrm{a}}$ & $0.00 \pm 0.00^{\mathrm{a}}$ \\
\hline
\end{tabular}

${ }^{\mathrm{a}-\mathrm{d}}$ Means \pm standard deviations followed by different superscript letters within the same row are significantly different at $\mathrm{p} \leq 0.05$ according to Tukey's test. 
In this study, the incorporation of Melastoma malabathricum extract into sodium alginate edible film does not exhibit any inhibitory effect against $S$. aureus. A possible explanation for this might be the concentration of Melastoma malabathricum extract is lesser to possess any inhibitory effect against bacteria even at the concentration of $6 \%(\mathrm{v} / \mathrm{v})$.

\section{Conclusions}

Edible film can be used to replace nonbiodegradable food packaging. Edible film forming materials classified into polysaccharide, protein and lipids.

Thus, this study was conducted to compare three types of polysaccharide-based edible film, which including chitosan, sodium alginate and carboxymethyl cellulose (CMC).

The results showed that sodium alginate edible film has better mechanical and physical properties compared to chitosan and CMC. Melastoma malabathricum extract was found to have high free radical scavenging effect and low total phenolic content.

The effect of different concentration of MME to the physical, mechanical and chemical properties of sodium alginate edible film was investigated in this study. With the addition of Melastoma malabathricum extract $(0 \%$ to $6 \% \mathrm{v} / \mathrm{v})$, the thickness, total color changes, antioxidant and total phenolic content of sodium alginate edible film was improved.

However, there was reduction in moisture content, water activity, elongation at break and no antibacterial activity. In conclusion, the addition of Melastoma malabathricum extract into sodium alginate edible film enhanced the functionality of the film as an active packaging.

\section{References}

Anbu, J., Jisha, P., Varatharajan, R., Muthappan, M. (2008). Antibacterial and wound healing activities of Melastoma malabathricum linn. African Journal of Infectious Diseases, 2(2), 6873.

Arham, R., Mulyati, M.T., Metusalach, M., Salengke, S. (2016). Physical and mechanical properties of agar based edible film with glycerol plasticizer. International Food Research Journal, 23(4), 1669-1675.

Bangyekan, C., Aht-Ong, D., Srikulkit, K. (2006). Preparation and properties evaluation of chitosan-coated cassava starch films. Carbohydrate Polymers, 63(1), 61-71.

Barbosa-Cánovas, G. (2007). Water activity in foods. Ames, Iowa: Blackwell Pub.

Benavides, S., Villalobos-Carvajal, R., Reyes, J. (2012). Physical, mechanical and antibacterial properties of alginate film: Effect of the crosslinking degree and oregano essential oil concentration. Journal of Food Engineering, 110(2), 232-239.

Biswal, D.R., Singh, R.P. (2004). Characterisation of carboxymethyl cellulose and polyacrylamide graft copolymer. Carbohydrate Polymers, 57(4), 379-387.

Bourtoom, T., Chinnan, M.S. (2008). Preparation and properties of rice starch-chitosan blend biodegradable film. LWT-Food Science and Technology, 41(9), 1633-1641.

Choong, K.W., Tee, Y.B., Nyam, K.L. and Pui, L.P. (2019). Antibacterial properties of chitosan edible films incorporated with musk lime extracts for the preservation of squids. Malaysian Journal of Analytical Sciences, 23(6), $914-925$.

Dai, Y.N., Li, P., Zhang, J.P., Wang, A.Q., Wei, Q. (2008). A novel $\mathrm{pH}$ sensitive $\mathrm{N}$ - 
succinyl chitosan/alginate hydrogel bead for nifedipine delivery. Biopharmaceutics and Drug Disposition, 29(3), 173-184.

Dhanapal, A., Sasikala, P., Rajamani, L., Kavitha, V., Yazhini, G., Banu, M.S. (2012). Edible films from polysaccharides. Food Science and Quality Management, 3, 9-17.

Eca, K.S., Sartori, T. and Menegalli, F.C. (2014). Films and edible coatings containing antioxidants-a review. Brazilian Journal of Food Technology, 17(2), 98-112.

Embuscado, M., Huber, K.C. (2009). Edible films and coatings for food applications. Berlin: Springer Science and Business Media.

Esmaeili, A., Fazel, M.E. (2016). Optimization and preparation of methylcellulose edible film combined with of Ferulago angulate essential oil (FEO) nanocapsules for food packaging application. Flavour and Fragrance Journal, 31(5), 341-349.

Fang, Z. (2016). Energy science and applied technology ESAT 2016. Milton: CRC Press.

Ghasemlou, M., Khodaiyan, F., Oromiehie, A. (2011). Physical, mechanical, barrier, and thermal properties of polyolplasticized biodegradable edible film made from kefiran. Carbohydrate Polymers, 84(1), 477-483.

Hebeish, A., Hashem, M., El-Hady, M.A., Sharaf, S. (2013). Development of CMC hydrogels loaded with silver nanoparticles for medical applications. Carbohydrate Polymers, 92(1), 407-413.

Hernandez-Hernandez, E., Ponce-Alquicira, E., Jaramillo-Flores, M.E., Legarreta, I.G. (2009). Antioxidant effect rosemary (Rosmarinus officinalis L.) and oregano (Origanum vulgare L.) extracts on TBARS and colour of model raw pork batters. Meat Science, 81(2), 410-417.
Jawaid, M., Qaiss, A., Bouhfid, R. (2016). Nanoclay reinforced polymer composites. Singapore: Springer.

Khoo, L.T., Abas, F., Abdullah, J.O., Tohit, M., Rahayu, E., Hamid, M. (2014). Anticoagulant activity of polyphenolicpolysaccharides isolated from Melastoma malabathricum L. EvidenceBased Complementary and Alternative Medicine, 2014.

Klimchuk, M.R., Krasovec, S.A. (2012). Packaging design: Successful product branding from concept to shelf. John Wiley and Sons.

Ma, Q., Zhang, Y., Zhong, Q. (2016). Physical and antimicrobial properties of chitosan films incorporated with lauric arginate, cinnamon oil, and ethylenediaminetetraacetate. LWT-Food Science and Technology, 65, 173-179.

Maizura, M., Fazilah, A., Norziah, M., Karim, A. (2007). Antibacterial activity and mechanical properties of partially hydrolyzed sago starch-alginate edible film containing lemongrass oil. Journal of Food Science, 72(6), C324-C330.

Maran, J.P., Sivakumar, V., Thirugnanasambandham, K., Kandasamy, S. (2013). Modeling and analysis of film composition on mechanical properties of maize starch based edible films. International Journal of Biological Macromolecules, 62, 565573.

Mishra, M. (2015). Handbook of encapsulation and controlled release. Milton: CRC Press.

Muppalla, S.R., Kanatt, S.R., Chawla, S.P., Sharma, A. (2014). Carboxymethyl cellulose-polyvinyl alcohol films with clove oil for active packaging of ground chicken meat. Food Packaging and Shelf Life, 2 (2), 51-58.

Nazzaro, F., Fratianni, F., De Martino, L., Coppola, R., De Feo, V. (2013). Effect 
of essential oils on pathogenic bacteria. Pharmaceuticals, 6(12), 1451-1474.

Ojagh, S.M., Rezaei, M., Razavi, S.H., Hosseini, S.M.H. (2010). Development and evaluation of a novel biodegradable film made from chitosan and cinnamon essential oil with low affinity toward water. Food Chemistry, 122(1), 161-166.

Pranoto, Y., Rakshit, S.K., Salokhe, V.M. (2005a). Enhancing antimicrobial activity of chitosan films by incorporating garlic oil, potassium sorbate and nisin. LWT-Food Science and Technology, 38(8), 859-865.

Pranoto, Y., Salokhe, V.M., Rakshit, S.K. (2005b). Physical and antibacterial properties of alginate-based edible film incorporated with garlic oil. Food Research International, 38(3), 267-272.

Remya, S., Mohan, C.O., Bindu, J., Sivaraman, G.K., Venkateshwarlu, G., Ravishankar, C.N. (2016). Effect of chitosan based active packaging film on the keeping quality of chilled stored barracuda fish. Journal of Food Science and Technology, 53 (1), 685-693.

Salbiah, M., Ling, S.K., Adilah, H.Z.A., Tan, A.L., Zunoliza, A. (2010). Differentiation of Melastoma malabathricum L. from different localities using FT-IR and 2D-IR Correlation Spectroscopy. Forest Research Institute Malaysia.

Sarbadhikary, S.B., Bhowmik, S., Datta, B.K., Mandal, N.C. (2015). Antimicrobial and antioxidant activity of leaf extracts of two indigenous angiosperm species of Tripura. International Journal of Current Microbiology and Applied Sciences, 4(8), 643-655.

Su, J.F., Huang, Z., Yuan, X.Y., Wang, X.Y., Li, M. (2010). Structure and properties of carboxymethyl cellulose/soy protein isolate blend edible films crosslinked by Maillard reactions. Carbohydrate Polymers, 79(1), 145-153. Suhaimy, I., Wahida, N., Azmi, N., Khusairi, A., Mohtarrudin, N., Omar, M.H., Tohid, S.F.M., Cheema, M.S., Teh, L.K., Salleh, M., Zakaria, Z.A. (2017). Semipurified ethyl acetate partition of methanolic extract of Melastoma malabathricum leaves exerts gastroprotective activity partly via its antioxidant-antisecretory-anti-

inflammatory action and synergistic action of several flavonoid-based compounds. Oxidative Medicine and Cellular Longevity, 2017, 1-14.

Suput, D., Lazic, V., Popovic, S., Hromis, N. (2015). Edible Films and Coatings Sources, Properties and Application. Food and Feed Research, 42(1), 11-22.

Susanti, D., Sirat, H.M., Ahmad, F., Ali, R.M. (2008). Bioactive constituents from the leaves of Melastoma malabathricum L. Jurnal Ilmiah Farmasi. 5(1), 1-7.

Susanti, D., Sirat, H.M., Ahmad, F., Ali, R.M., Aimi, N., Kitajima, M. (2007). Antioxidant and cytotoxic flavonoids from the flowers of Melastoma malabathricum L. Food Chemistry, 103(3), 710-716.

Varela, P., Fiszman, S.M. (2011). Hydrocolloids in fried foods. A review. Food Hydrocolloids, 25(8), 1801-1812.

Wong, Y.H., Lau, H.W., Tan, C.P., Long, K., Nyam, K.L. (2014). Binary solvent extraction system and extraction time effects on phenolic antioxidants from kenaf seeds (Hibiscus cannabinus L.) extracted by a pulsed ultrasonic-assisted extraction. The Scientific World Journal, 2014, 1-7.

Zaman, N. B. K., Lin, N.K., Phing, P.L. (2018). Chitosan film incorporated with Garcinia atroviridis for the packaging of Indian mackerel (Rastrelliger 
kanagurta). Ciência e Agrotecnologia, 42(6), 666-675.

Acknowledgment

This study was conducted and fully supported by UCSI PSIF (Pioneer Scientist Incentive Fund) fund (Proj-In-FAS-056). 